\title{
FORMULASI DAN UJI AKTIVITAS ANTIBAKTERI SEDIAAN FOOTSPRAY ANTI BAU KAKI YANG MENGANDUNG EKSTAK KULIT JERUK NIPIS DAN AMPAS KOPI
}

\author{
Finna Ashfia ${ }^{1^{\star}}$, Fidelia Yustisia Adriane ${ }^{1}$, Devy Puspita Sari ${ }^{1}$, Rusmini $^{1}$ \\ ${ }^{1}$ Jurusan Kimia, Universitas Negeri Surabaya, Jalan Ketintang, Surabaya, 60231 \\ * Author Utama, email: finnaashfia16030234023@mhs.unesa.ac.id \\ Co-author 1, email: fidelia.17030234049@mhs.unesa.ac.id \\ Co-author 2, email: devy.17030234004@mhs.unesa.ac.id \\ Co-author 3, email: rusmini@unesa.ac.id
}

\begin{abstract}
Lime skin and coffee grounds are wastes still contain flavonoids which have the potential to be antibacterial so both can be used as inhibitors of bacterial growth. This study aims to determine the antibacterial activity in the footspray preparation with extract variations of 0.05; 0,1; and 0.15 and determine the results of the organoleptic test and physical test of antibacterial footspray. This research was started by extracting lime and coffee grounds using maceration method so that thick extracts were obtained to proceed with spray formulation. The resulting preparations were then tested organoleptically and physisically including color, smell, $\mathrm{pH}$, viscosity, and dry time, and their antibacterial activity using culture of Staphylococcus epidermidis bacteria. The results of this study indicate that along with the addition of extracts, the resulting color becomes more concentrated, the smell fades, and the dry time gets faster, and the thickness increases. In each formula has the same $\mathrm{pH}$, it is 5. Antibacterial activity in the spray preparation was tested by the disc diffusion method with clear zone observations. The antibacterial activity test in this preparation produced a bacterial inhibitory zone in $F 1$ of $4 \mathrm{~mm}$, F2 of $5 \mathrm{~mm}$, and F3 of $6 \mathrm{~mm}$. So that it can be concluded that the preparation with the addition of extract has the most bacteria inhibitory zone at the most.
\end{abstract}

Keywords : Lime skin; coffee ground; Antibacteria; Footspray.

ABSTRAK

Kulit jeruk nipis dan ampas kopi merupakan limbah yang masih memiliki kandungan senyawa aktif berupa flavonoid yang berpotensi sebagai zat antibakteri sehingga keduanya dapat digunakan sebagai penghambat pertumbuhan bakteri. Penelitian ini bertujuan untuk mengetahui hasil uji organoleptis dan sediaan fisik footspray antibakteri dan mengetahui aktivitas antibakteri pada sediaan footspray dengan variasi ekstrak 0,05; 0,1; dan 0,15. Penelitian ini diawali dengan ekstraksi kulit jeruk nipis dan ampas kopi menggunakan metode maserasi sehingga didapatkan ekstrak kental dilanjut dengan melakukan formulasi sediaan spray. Sediaan yang dihasilkan selanjutnya diuji organoleptis dan sediaan fisik meliputi warna, aroma, $\mathrm{pH}$, viskositas, dan waktu kering, serta aktivitas antibakterinya menggunakan biakan bakteri Staphylococcus epidermidis. Hasil penelitian ini menunjukkan bahwa seiring dengan penambahan ekstrak, warna yang dihasilkan semakin pekat, aroma yang semakin memudar, serta waktu kering yang semakin cepat, serta kekentalan yang semakin besar. Pada masing - masing formula memiliki pH yang sama, yaitu 5. Aktivitas antibakteri pada sediaan spray telah diuji dengan metode difusi cakram dengan pengamatan zona bening. Uji aktivitas antibakteri pada sediaan ini menghasilkan diameter zona hambat bakteri pada F1 sebesar $4 \mathrm{~mm}$, F2 sebesar $5 \mathrm{~mm}$, dan F3 sebesar $6 \mathrm{~mm}$. Hasil yang didapatkan sesuai dengan teori dimana semakin banyak penambahan senyawa antibakteri pada ektrak kulit jeruk nipis dan ampas kopi dapat meningkatkan aktivitas antibakteri pada sediaan footspray.

Kata Kunci: Kulit Jeruk Nipis; Ampas Kopi; Antibakteri; Footspray. 


\section{PENDAHULUAN}

Peningkatan suhu bumi menyebabkan produksi keringat pada manusia menjadi lebih banyak sehingga dapat meningkatkan kelembapan dan berdampak pada mekanisme penguapan keringat [1]. Salah satu bagian tubuh yang memproduksi keringat dengan frekuensi lebih banyak adalah kaki karena pada bagian tersebut sering ditutupi dengan penggunaan kaos kaki dan sepatu. Keadaan kaki yang sering tertutup serta didukung dengan suhu yang tinggi dapat memicu timbulnya masalah pada kaki, salah satunya adalah bau kaki [2].

Permasalahan bau kaki tidak hanya mengganggu penampilan, namun akan berdampak pada hubungan sosial serta dapat menjadi pertanda kehigienisan yang buruk. Bau kaki disebabkan oleh adanya bakteri pada permukaan kulit dan sepatu. Bakteri seperti Staphylococcus menyebabkan timbulnya bau tidak sedap dengan mendegradasi leusin yang dihasilkan oleh keringat, sehingga terbentuk asam isovalerat yang menebarkan bau tidak sedap [1]. Permasalahan seperti ini dapat diatasi dengan penggunaan antibakteri yang mampu menghambat aktivitas pertumbuhan bakteri penyebab bau kaki.

Senyawa aktif yang dapat berperan sebagai antibakteri terdapat pada ampas kopi dan kulit jeruk nipis. Ampas kopi merupakan produk hasil samping dari pengolahan kopi. Sekitar 6 juta ton ampas kopi diproduksi di dunia setiap tahun oleh industri kopi [3]. Ampas kopi merupakan salah satu limbah yang masih belum banyak dimanfaatkan kelebihannya. Ampas kopi yang tersisa masih memiliki kandungan seperti kafein, asam organik, mineral, antioksidan, serta senyawa aktif seperti flavonoid meskipun tidak sebanyak kopi bubuk murni [4]. Menurut penelitian Aprilia [5] ampas kopi juga memiliki zat antibakteri alami sehingga dapat mengatasi bau kaki. Ampas kopi dipilih menjadi bahan antibakteri karena selain mudah untuk diaplikasikan sebagai obat, ampas kopi juga mudah ditemukan.

Jeruk nipis merupakan salah satu buah yang kaya akan manfaat. Daun, buah, maupun kulit jeruk nipis memiliki manfaat sebagai antibakteri karena didalamnya mengandung minyak atsiri yaitu senyawa flavonoid yang mampu menghambat pertumbuhan bakteri [6]. Kulit jeruk nipis mengandung bahan aktif seperti tanin, saponin, flavonoid, dan alkaloid yang diduga dapat memberikan efek antibakteri [7]. Minyak atsiri dapat meningkatkan fluiditas dan permeabilitas membran sehingga merusak membran yang mengikat protein transport, menghambat respirasi, dan merubah proses transpor ion dalam bakteri [8] - [9].

Anti bau kaki telah banyak diproduksi, seperti bodyscrub antibakerti dan sabun antibakteri. Salah satu sediaan farmasi yang banyak ditemui dipasaran adalah bentuk spray, yang digunakan pada wajah, tangan, maupun kaki. Bentuk spray dipilih atas dasar sifat spray yang dapat memberikan suatu kandungan yang konsentrat, namun di saat yang bersamaan memiliki profil yang cepat kering sehingga serta mudah dipakai untuk pengguna. 


\section{METODE PENELITIAN}

Material

Alat

Alat yang digunakan dalam penelitian ini adalah rotary evaporator (Buchi), pompa vakum, corong buchner, viskometer ostwald, batang pengaduk, oven, piknometer, botol spray, dan gelas kimia (pyrex $250 \mathrm{~mL}$ ).

\section{Bahan}

Bahan yang digunakan pada penelitian ini adalah biakan bakteri S. Aureus (Universitas Negeri Surabaya), media NB, propilen glikol, gliserin, isopropil alkohol, tween 80 , mentol, etanol $96 \%$, aquades, ampas kopi, dan kulit jeruk nipis.

\section{Prosedur}

\section{Ekstraksi Kulit Jeruk Nipis dan Ampas} Kopi

Tahap pertama pada prosedur ini adalah mengumpulkan bahan pembuatan ekstrak yaitu kulit jeruk nipis dan ampas kopi. Kemudian dikeringkan menggunakan oven pada suhu $60^{\circ} \mathrm{C}$ dan diblender hingga menjadi serbuk.

Pembuatan ekstrak menggunakan metode maserasi dengan pelarut etanol $96 \%$. Serbuk sampel yang telah disiapkan direndam dalam etanol $96 \%$, diaduk agar homogen, dan didiamkan selama 24 jam. Setelah 24 jam disaring dan di evaporasi untuk menghilangkan pelarut hingga didapatkan ekstrak kental kulit jeruk nipis dan ampas kopi.

\section{Formulasi Spray}

Ekstrak yang didapatkan pada tahap ekstraksi disimpan dalam wadah untuk digunakan dalam tahap formulasi. Pembuatan formulasi sediaan foot spray mengacu pada penelitian Iswandana dan Lidya (2017) seperti yang tercantum pada Tabel 1 .

Tabel 1. Formula Spray

\begin{tabular}{llllc} 
& Bahan & \multicolumn{4}{c}{ Formula (\%b/v) } \\
\cline { 2 - 5 } & $\mathrm{F} 1$ & $\mathrm{~F} 2$ & $\mathrm{~F} 3$ & Kontrol \\
\hline $\begin{array}{l}\text { Ekstrak } \\
\text { ampas } \\
\text { kopi }\end{array}$ & 0,05 & 0,1 & 0,15 & - \\
\hline $\begin{array}{l}\text { Ekstrak } \\
\text { jeruk } \\
\text { nipis }\end{array}$ & 0,05 & 0,1 & 0,15 & - \\
\hline Gliserin & 0,2 & 0,2 & 0,2 & 0,2 \\
\hline $\begin{array}{l}\text { Isopropil } \\
\text { alkohol }\end{array}$ & 5 & 5 & 5 & 5 \\
\hline Mentol & 1 & 1 & 1 & 1 \\
\hline Propilen- & 5 & 5 & 5 & 5
\end{tabular}

glikol

\begin{tabular}{lcccc}
\hline $\begin{array}{l}\text { Karbopol } \\
940\end{array}$ & 0,06 & 0,06 & 0,06 & 0,06 \\
\hline Pewangi & 1,5 & 1,5 & 1,5 & 1,5 \\
\hline Tween & 4,3 & 4,3 & 4,3 & 4,3
\end{tabular}

80

\begin{tabular}{lllll}
\hline Aquades & Ad & Ad & Ad & Ad \\
& 100 & 100 & 100 & 100
\end{tabular}

\section{HASIL DAN PEMBAHASAN}

\section{Ekstraksi Kulit Jeruk Nipis dan Ampas Kopi}

Ekstrak etanol 96\% kulit jeruk nipis dan ampas kopi yang didapatkan berupa ekstrak kental. Ekstrak etanol kulit jeruk nipis yang didapatkan berwarna hujau kehitaman dengan aroma etanol yang tajam. Sedangkan ekstrak etanol ampas kopi yang didapatkan berwarna coklat dan beraroma khas kopi bercampur dengan aroma etanol. 


\section{Formulasi Spray}

Penelitian ini menggunakan 3 variasi formula dengan kontrol. Penggunaan variasi konsentrasi ekstrak kulit jeruk nipis dan ampas kopi bertujuan untuk mengetahui efektivitas kandungan ekstrak etanol kulit jeruk nipis dan ampas kopi terhadap aktivitas antibakteri [9]. Kontrol tidak mengandung ekstrak etanol kulit jeruk nipis dan ampas kopi. Formula 1 mengandung ekstrak etanol kulit jeruk nipis dan ampas kopi masing masing dengan konsentrasi $0,05 \%$, formula 2 mengandung ekstrak etanol kulit jeruk nipis dan ampas kopi masing - masing dengan konsentrasi $0,1 \%$, dan formula 3 mengandung ekstrak etanol kulit jeruk nipis dan ampas kopi masing - masing dengan konsentrasi $0,15 \%$.

Sediaan spray dibuat sedikit kental untuk menjaga stabilitas kandungan didalam sediaan. Oleh karena itu dilakukan penambahan karbopol agar sediaan spray sedikit kental namun dapat mengalir [9]. Bahan karbopol dipilih karena memiliki kompabilitas yang baik dengan bahan bahan lain didalam formulasi. Pada penggunaannya dalam kosmetik, karbopol tidak meninggalkan bekas saat digunakan. Hasil sediaan spray dapat dilihat pada Gambar 1.

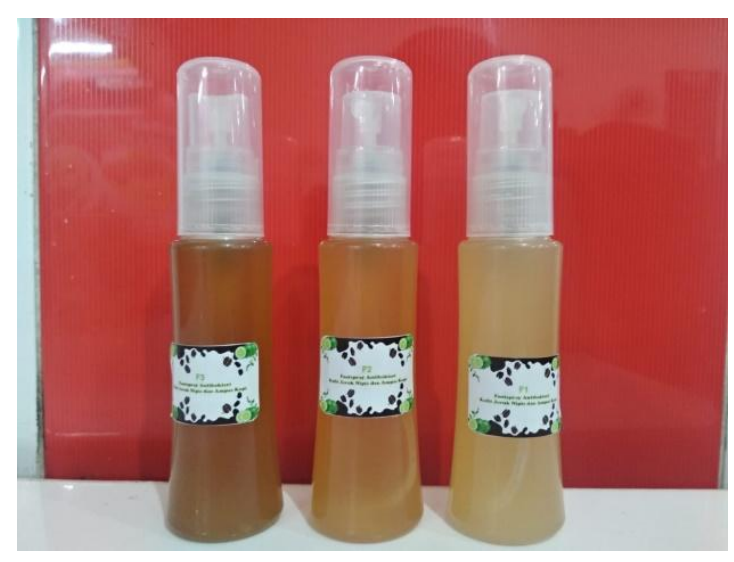

Gambar 1. (a) Formula 3, (b) Formula 2, (c) Formula 1

\section{Uji Organoleptis}

Evaluasi organoleptis meliputi warna, aroma, dan rasa. Pada formula 1, formula 2, dan formla 3 berturut-turut memiliki warna kuning keruh beraroma mentol sangat menyengat, coklat kekuningan beraroma mentol menyengat, dan coklat beraroma mentol tidak terlalu menyengat. Sedangkan pada kontrol memiliki warna putih keruh dan beraroma mentol menyengat. Ketiga formulasi memiliki rasa yang sama, yaitu menghasilkan rasa dingin ketika diaplikasikan ada kulit.

\section{Uji Sediaan Fisik}

Evaluasi sediaan fisik meliputi $\mathrm{pH}$, viskositas, dan waktu kering sediaan spray. Dalam sediaan kosmetik, rentang $\mathrm{pH}$ sediaan harus sesuai dengan $\mathrm{pH}$ kulit yaitu 4,5 - 6,5 [9]. Berdasarkan hasil uji $\mathrm{pH}$ yang telah dilakukan, sediaan spray memiliki pH 6 . Selanjutnya dilakukan uji viskositas yang bertujuan untuk mengetahui tingkat kekentalan suatu produk. Uji viskositas menggunakan alat viskometer ostwald. Hasil uji viskositas dapat dilihat pada tabel 2 . 
Tabel 2. Hasil Uji Viskositas

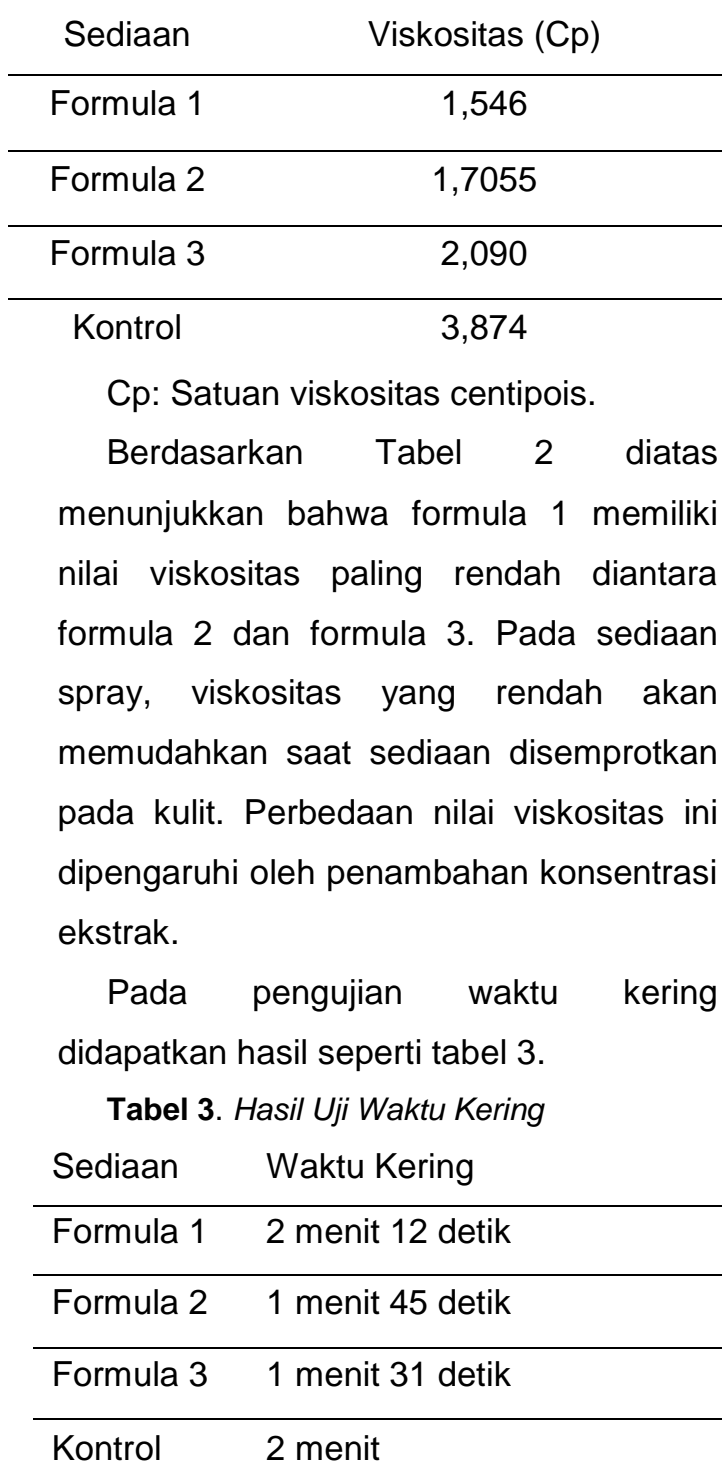

\section{Uji Antibakteri}

Aktivitas antibakteri sediaan spray dapat dilihat dari terbentuknya zona bening disekitar sumuran media yang disebut sebagai zona hambat. Hasil uji antibakteri sediaan spray dapat dilihat pada gambar dibawah :

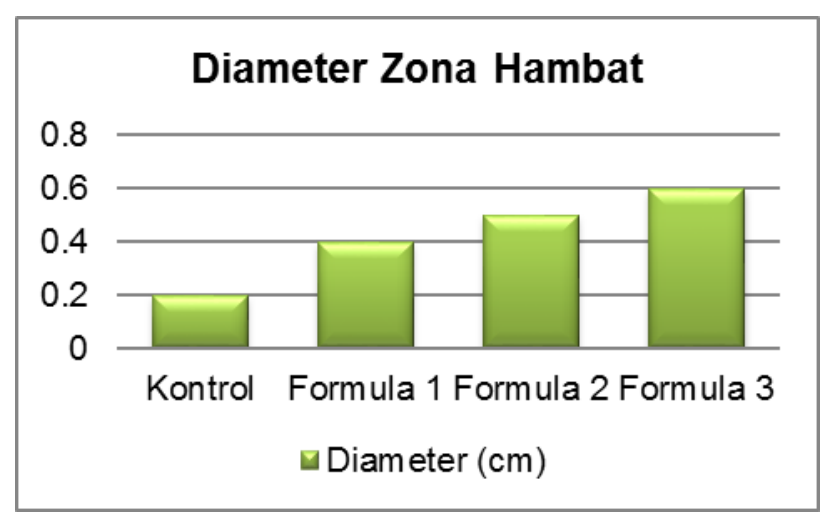

Gambar 2. Diameter zona bening sediaan

Cakram yang digunakan pada uji memiliki diameter $5 \mathrm{~mm}$. Sediaan formula 1 memiliki diameter zona bening sebesar $4 \mathrm{~mm}$, formula 2 diperoleh diameter zona bening sebesar $5 \mathrm{~mm}$, formula 3 diperoleh diameter zona bening sebesar $6 \mathrm{~mm}$, dan kontrol diperoleh diameter zona bening sebesar 2 $\mathrm{mm}$. Diameter zona hambat dilakukan dengan mengukur selisih antara diameter zona hambat dengan diameter cakram.

Berdasarkan hasil uji dapat diketahui bahwa formula 3 memiliki zona hambat paling besar daripada formula 1 dan formula 2. Hal ini dikarenakan pada formula 3 dilakukan penambahan ekstrak paling banyak, yaitu sebesar $0,15 \% \quad b / v$ sehingga kandungan flavonoid yang terkandung didalam sediaan ekstrak juga semakin besar. Hasil penetapan zona hambat bakteri menunjukkan bahwa dibutuhkan $0,15 \% \mathrm{~b} / \mathrm{v}$ ekstrak kulit jeruk nipis dan ampas kopi untuk membentuk zona hambat minimum bakteri S. Epidermidis.

\section{KESIMPULAN}

Berdasarkan hasil yang telah diperoleh dapat disimpulkan bahwa semakin banyak penambahan ekstrak kulit jeruk nipis dan ampas kopi maka aktivitas antibakteri sediaan spray semakin meningkat, serta hasil uji 
organoleptis menunjukkan warna dan aroma sediaan yang semakin pudar, namun tidak terdapat perbedaan rasa. Sediaan fisik spray memiliki waktu kering yang semakin cepat, nilai viskositas yang semakin tinggi, serta $\mathrm{pH}$ yang sama yaitu 5 .

\section{DAFTAR PUSTAKA}

[1] Tiran, F. A., \& Nastiti, C. M. "Aktivitas Antibakteri Lotion Minyak Kayu Manis Terhadap Staphylococcus epidermidis Penyebab Bau Kaki". Jurnal Farmasi Sains dan Komunitas, 72-80, 2014.

[2] (2011) The Society of Chiropodists \& Pediatrists. Sweaty Feet. [Online]. http://www.scop.org/foot/health/common-foot-problems/sweaty-feet/ diakses tanggal 29 September 2018.

[3] Mebrahtu H. "Integrated Volarization of Spent Coffee Grounds to Biofuel". Biofuel Research Journal. 2(2), 65-69, 2014.

[4] Acevedo F, Rubilar M, Scheuermann E, Cancino B, Uquiche E, Garces M, Inostroza K, Shene C.
"Bioactive compounds of spent coffee grounds, a coffee industrial residue. Symposium on agricultural and agroindustrial waste management" : 1-4. 2013.

[5] Aprilia A. A. Antimicrobial and antioxidant activities of microwave assisted extracts from coffee ground residue in Chiang rai province, Thailand [Skripsi]. Bogor (ID) : Institut Pertanian Bogor. 2013.

[6] Wardani, R., Jekti, D. S., \& Sedijani, P. “Uji Aktivitas Antibakteri Ekstrak Kulit Buah Jeruk Nipis (Citrus aurantifolia swingle) Terhadap Pertumbuhan Bakteri Isolat Klinis". Jurnal Penelitian Pendidikan IPA, 2018.

[7] Robinson, T. Kandungan Organik Tumbuhan Tingkat Tinggi. Bandung: ITB. 1991.

[8] Sikkema J, Bont JAM de, poolman B. "Interaction of cyclic hydrocarbons with biological membranes. Journal of Biologycal Chem", 269(11), page : 80228028. 1994.

[9] Iswandana, R., \& Sihombing, L. K. Formulasi, Uji Stabilitas Fisik, dan Uji Aktivitas Secara In Vitro Sediaan Spray Antibau Kaki yang Mengandung Kestrak Etanol Daun Sirih (Piper betle L.). 4 No. 3,2017. 